\title{
Impact of leaching on chloride ingress profiles in concrete
}

\author{
Alisa Machner (1D - Marie Bjørndal • Aljoša Šajna • Nikola Mikanovic • \\ Klaartje De Weerdt
}

Received: 28 August 2020/ Accepted: 25 April 2021/Published online: 23 December 2021

(C) The Author(s) 2021

\begin{abstract}
To investigate the effect of leaching on chloride ingress profiles in concrete and mortar, we exposed concrete and mortar specimens for 90 and 180 days to two different exposure solutions: $3 \%$ $\mathrm{NaCl}$, and $3 \% \mathrm{NaCl}$ with $\mathrm{KOH}$ added to limit leaching. The solutions were replaced weekly. After exposure, we determined total chloride profiles to investigate the chloride ingress, and portlandite profiles to assess the extent of leaching. The results showed that leaching during exposure greatly affects the chloride ingress profiles in mortar and concrete. We found that leaching leads to considerably higher maximum total
\end{abstract}

Supplementary Information The online version contains supplementary material available at https://doi.org/10.1617/ s11527-021-01730-w.

A. Machner $(\square)$

Centre for Building Materials, Professorship for Mineral Construction Materials, Technical University of Munich, Franz-Langinger-Straße 10, 81245 Munich, Germany e-mail: alisa.machner@tum.de

\section{Bjørndal · K. De Weerdt} Department of Structural Engineering, NTNU, Richard Birkelandsvei 1A, 7491 Trondheim, Norway

\section{A. Šajna}

Slovenian National Building and Civil Engineering Institute, Dimičeva 12, 1000 Ljubljana, Slovenia

N. Mikanovic

HeidelbergCement Technology Center, Oberklamweg 6, 69181 Leimen, Germany chloride content and deeper chloride penetration into the concrete than in the specimens where leaching was limited. We recommend therefore that leaching should be taken into account in standard laboratory testing and that more mechanistic service life models should be used to take into account the impact of leaching.

Keywords Chloride ingress $\cdot$ Service life prediction $\cdot$ Leaching $\cdot$ Concrete $\cdot$ Portlandite

\section{Introduction}

Today's society calls for sustainable structures with low carbon footprints, limited use of natural resources, and the resilience to withstand mechanical, chemical and environmental impacts. One of the most common deterioration mechanisms in reinforced concrete structures is corrosion of the reinforcement steel. In concrete structures exposed to a marine environment or de-icing salts, reinforcement corrosion is generally induced by chlorides penetrating the concrete cover and enabling pitting corrosion as they reach a critical content at the steel surface. Concrete covers must be resistant to chloride penetration and we need to improve our understanding of the mechanisms involved, if we are to design sustainable reinforced concrete structures with a reliable service life.

To assess how far chlorides have penetrated the concrete cover, chloride profiles are determined by 
giving the total chloride content in the concrete (e.g. as $\mathrm{wt} \%$ of concrete powder) as a function of the depth from the exposed surface. The total chloride content comprises chlorides present in the pore solution, commonly referred to as free chlorides, and chlorides that interact with the cement hydrates, referred to as bound chlorides [1-9]. The bound chlorides can be either chemically bound in chloride-containing AFm phases, such as Friedel's salt or Kuzel's salt, or physically bound by accumulating in the diffusive layer of the $\mathrm{C}-\mathrm{S}-\mathrm{H}$ phase $[7,10,11]$.

Service life prediction models are used to assess how long it will take for the chlorides to reach a critical content at the reinforcement. The most commonly used models for chloride ingress prediction are based on Fick's 2nd law of diffusion, e.g. fib Bulletin 34 [12]. In these models, the error function solution of Fick's 2nd law is fitted to a measured chloride profile. This approach solely considers the ingress of chlorides; the potential influence of other ions present in sea water, such as sodium, sulphate and magnesium, or of ions leached from the pore solution, such as calcium or potassium, is not considered.

In previous studies on chloride ingress in fieldexposed concrete submerged in sea water, the chloride profiles exhibited a bell-like shape [13, 14]. This entails that the chloride content is lower at the surface than it is slightly deeper into the concrete. Such a belllike shape or "peaking-behaviour" in total chloride profiles has commonly been attributed to the wetting and drying of the concrete, where the capillary suction of chloride-containing exposure solutions leads to an accumulation of chlorides near the surface, whereas exposure to wind and precipitation may wash out chlorides at the surface [15]. This is not a valid explanation for the peaking-behaviour in submerged concrete where no wetting and drying takes place. Others have attributed the peaking-behaviour in concrete submerged in sea water to the presence of sulphate ions, which compete with chloride ions in binding to the solids $[3,16,17]$. In a recent study, however, similar peaking behaviour was observed for mortars submerged in a $\mathrm{NaCl}$ solution as for mortars submerged in sea water [13]. Therefore, the additional ions in sea water do not explain the peaking behaviour in submerged concrete. This led to the hypothesis that leaching might provoke the peaking-behaviour by affecting the chloride-binding capacity in the concrete near the exposed surface. This would make leaching the main explanation for what in engineering practice has been referred to as age-dependent chloride surface content. This age-dependent chloride surface content is not understood and, if considered at all, is fitted with empirically determined coefficients [18] that lead to large deviations in the predicted service life of reinforced concrete structures.

To investigate the impact of leaching on chloride binding, we previously designed a set of experiments in which cement paste was artificially leached using $\mathrm{HCl}$ and subsequent changes in its chloride-binding capacity were measured [19]. We observed that a slight reduction in the $\mathrm{pH}$ (down to 12) led to an increase in the chloride-binding capacity of the paste, whereas a severe decrease in the $\mathrm{pH}$ (down to 9) led to a drastic reduction in its chloride-binding capacity [19]. This led to the hypothesis that gradual leaching during exposure of concrete to a $\mathrm{NaCl}$ solution or sea water would lead to an increase in chloride binding with time and consequently to an increased total chloride content in the concrete. This would move the chloride ingress profiles to higher total chloride values with time. At the concrete surface, the leaching could be so advanced that it causes the dissolution of the hydration phases that bind chlorides. This would then cause a drastic reduction in chloride binding and therefore a reduced total chloride content in the outermost section of the sample. The combined effects of moderate and advanced leaching could explain the so-called "peaking-behaviour" in the chloride profiles in submerged concrete.

To put our hypothesis to the test, we designed the experimental set-up presented in the current study. The set-up bears similarities to commonly used laboratory tests for chloride ingress in concrete [20-24]. Two parallel sets of mortar and concrete cylinders were submerged in two different exposure solutions, which were replaced weekly over a period of 90 and 180 days. The special feature in the set-up lies in the composition of the exposure solutions. The first exposure solution is simply a $3 \% \mathrm{NaCl}$ solution, which has a chloride concentration similar to sea water and is commonly applied in conventional laboratory tests $[21,22,24]$. The second exposure solution also contains $3 \% \mathrm{NaCl}$, but in addition contains $\mathrm{KOH}$ in a concentration aimed at mimicking the $\mathrm{KOH}$ concentration in the pore solution of the CEM II/C-M (S-LL) cement used in this study $(150 \mathrm{mMol} / \mathrm{L})$. We used thermodynamic modelling to predict this. We chose a 
$\mathrm{KOH}$ concentration similar to the concentration in the pore solution to limit leaching in these specimens during exposure. The high potassium concentration in the exposure solution prevents potassium leaching from the pore solution, but more importantly, it also results in a high $\mathrm{pH}$, which keeps the solubility of calcium low. This reduced leaching of calcium from the specimens during exposure and enabled us to investigate the impact of leaching on the chloride profiles in the exposed specimens.

After exposure, the mortar and concrete specimens were profile ground to obtain samples from which total chloride profiles were determined. To assess the extent of leaching, we focused on calcium, specifically portlandite $\left(\mathrm{Ca}(\mathrm{OH})_{2}\right)$, as this is one of the first hydration phases to decompose in the event of leaching [25]. Other hydration phases start to decompose only after most of the portlandite has been dissolved [26, 27]. Portlandite profiles were determined on the profile ground mortar and concrete using thermogravimetric analysis (TGA).

\section{Experimental}

\subsection{Materials and mixture proportions}

The experiments in this study were performed on mortar and concrete specimens containing low-clinker cement developed within the scope of the EU-funded EnDurCrete project (www.endurcrete.eu). The CEM II/C-M(S-LL) cement used in this study contains $50 \mathrm{wt} \%$ CEM I $52.5 \mathrm{R}, 40 \mathrm{wt} \%$ ground granulated blast-furnace slag (GGBFS), and $10 \mathrm{wt} \%$ limestone filler. Table 1 shows the chemical composition of the cement as determined by XRF. The cement was designed and produced by Heidelberg Cement on principles described in Bolte et al. [28]. The European Standardization Committee is currently working on adding this type of low-clinker cement to the family of common cements within the scope of EN 197-1 [29].

Table 2 shows the concrete and mortar mixtures used in this study. The concrete composition was also developed in the EnDurCrete project, with the intention to test its functionality under severe operating conditions at two maritime demonstrator sites [30]. The concrete was proportioned to fulfil the performance requirements related to the specificity of the
Table 1 Chemical composition [wt\%] of the cement used in this study (CEM II/ $\mathrm{C}-\mathrm{M}(\mathrm{S}-\mathrm{LL}))$ as determined by XRF, density $\left[\mathrm{g} / \mathrm{cm}^{3}\right]$ and the Blaine specific surface area $\left[\mathrm{cm}^{2} / \mathrm{g}\right]$

\begin{tabular}{ll}
\hline Oxide & [wt\%] \\
\hline $\mathrm{LOI}$ & 4.36 \\
$\mathrm{SiO}_{2}$ & 24.18 \\
$\mathrm{Al}_{2} \mathrm{O}_{3}$ & 7.16 \\
$\mathrm{TiO}_{2}$ & 0.56 \\
$\mathrm{MnO}$ & 0.10 \\
$\mathrm{Fe}_{2} \mathrm{O}_{3}$ & 1.39 \\
$\mathrm{CaO}$ & 53.67 \\
$\mathrm{MgO}$ & 3.23 \\
$\mathrm{~K}_{2} \mathrm{O}$ & 0.71 \\
$\mathrm{Na}_{2} \mathrm{O}$ & 0.18 \\
$\mathrm{SO}_{3}$ & 4.08 \\
$\mathrm{P}_{2} \mathrm{O}_{5}$ & 0.07 \\
Total & 99.69 \\
Density $\left[\mathrm{g} / \mathrm{cm}^{3}\right]$ & 2.98 \\
$\mathrm{Blaine}^{2}\left[\mathrm{~cm}^{2} / \mathrm{g}\right]$ & 5210 \\
\hline
\end{tabular}

demonstrator case (type of structure, required rheological properties of the concrete, structural and service requirements of the structure). The fine and coarse aggregates used in this study are the same as those to be used for the production of the demonstrator specimens, namely natural limestone/quartz river sand and intermediate $(5 / 10 \mathrm{~mm})$ and coarse $(10 / 15 \mathrm{~mm})$ river gravel. Their grading is shown in Table 3 . ViscoCrete 2014 PCE-based superplasticizer intended for all types of precast applications was used in combination with a ViscoFlow 26 workability-retaining admixture to achieve a highly fluid concrete of S5 consistency according to EN 206 [31] without significant workability loss over time and additional retardation.

The mortar composition was obtained from the composition developed for the concrete by simply removing the intermediate and coarse aggregates. The amount of water was reduced by the amount of water adsorbed on gravel particles. This means the mortar and the underlying concrete have slightly different effective water-to-binder (w/b) ratios. The relative dosage of superplasticizer and workability-retaining admixture was kept constant, but the total amount of admixtures was adjusted, to ensure a similar workability compared to that of concrete. 
Table 2 Mix compositions for the mortar and concrete tested in this study, including the effective $\mathrm{w} / \mathrm{b}$ ratios

\begin{tabular}{lll}
\hline & Concrete $\left[\mathrm{kg} / \mathrm{m}^{3}\right]$ & Mortar $\left[\mathrm{kg} / \mathrm{m}^{3}\right]$ \\
\hline CEM II / C-M (S-LL) & 360 & 561.6 \\
Natural sand 0/4 & 968 & 1510 \\
Gravel 5/10 & 390 & - \\
Gravel 10/15 & 575 & - \\
Superplasticizer & 1.91 & 1.89 \\
Workability-retaining & 2.87 & 2.83 \\
adm. & & \\
Water & 162 & 240.7 \\
w/b ratio (effective) & 0.45 & 0.43 \\
\hline
\end{tabular}

Table 3 Particle size distribution of aggregates

\begin{tabular}{llll}
\hline Sieve size & \multicolumn{2}{l}{ Total wt\% passing } \\
\cline { 2 - 4 } & $0 / 4$ sand & $5 / 10$ gravel & $10 / 15$ gravel \\
\hline $31.5 \mathrm{~mm}$ & & 100 & 100 \\
$16 \mathrm{~mm}$ & & 68 & 98 \\
$8 \mathrm{~mm}$ & 100 & 1 & 18 \\
$4 \mathrm{~mm}$ & 94 & 0.3 & 0.3 \\
$2 \mathrm{~mm}$ & 76 & & \\
$1 \mathrm{~mm}$ & 59 & & \\
$500 \mu \mathrm{m}$ & 37 & & \\
$250 \mu \mathrm{m}$ & 15 & & \\
$125 \mu \mathrm{m}$ & 6 & & \\
$63 \mu \mathrm{m}$ & 2 & & \\
\hline
\end{tabular}

\subsection{Test specimen preparation}

Mortar and concrete mixtures were prepared in the laboratory at $23{ }^{\circ} \mathrm{C} \pm 2{ }^{\circ} \mathrm{C}$ using a planetary concrete mixer (Galletti P50) with $50 \mathrm{~L}$ capacity. Batches of $40 \mathrm{~L}$ were mixed in accordance with the following procedure: all solid components were mixed for $20 \mathrm{~s}$ at $30 \mathrm{rpm}$; approximately $3 / 4$ of the mixing water was then added, followed by mixing for $60 \mathrm{~s}$ at $59 \mathrm{rpm}$; finally, the remaining mixing water and admixtures were added, followed by mixing for another $10 \mathrm{~min}$ at $59 \mathrm{rpm}$.

The mortar and concrete mixtures were cast in cylindrical moulds (height: $200 \mathrm{~mm}$, diameter: $100 \mathrm{~mm}$ ). The moulds were filled and slightly stroked to ensure proper filling. The cylinders were then covered with a plastic plate, stored in the laboratory and demoulded after 1 day, when they were placed in a humidity chamber $\left(95 \% \mathrm{RH}, 20^{\circ} \mathrm{C}\right)$ for 21 days.
They were then sealed in a plastic foil and kept at $20{ }^{\circ} \mathrm{C}$ until reaching an age of 56 days. A total of 8 concrete cylinders and 8 mortar cylinders were cast for this study (Table 4).

One test specimen was sawn from each cylinder (Fig. 1 and Table 4). Each test specimen was then vacuum-saturated with deionized water in a $100 \mathrm{~L}$ tank at an absolute pressure of approx. 2 mbar. $24 \mathrm{~h}$ after vacuum saturation, the specimens were dried under laboratory conditions until the surfaces appeared dry (approx. $6 \mathrm{~h}$ ), and all surfaces of the test specimens except the sawn surface were sealed with epoxy. The epoxy-sealed specimens were then dried overnight under laboratory conditions. Before exposure, the test specimens were immersed in $2 \mathrm{~L}$ of a calcium hydroxide saturated solution for $18 \mathrm{~h}$. The whole procedure was performed in accordance with EN 12390-11 [24].

\subsection{Exposure}

Half of the concrete and mortar test specimens were immersed in a $3 \% \mathrm{NaCl}$ solution and the other half were immersed in a $3 \% \mathrm{NaCl}+\mathrm{KOH}$ solution, both in sealed boxes at $20{ }^{\circ} \mathrm{C}$ for 90 or 180 days (see Fig. 1 and Table 4). The exposure solutions were replaced weekly. The $3 \% \mathrm{NaCl}$ solution was prepared by dissolving $30 \mathrm{~g}$ of analytical grade $\mathrm{NaCl}$ (supplied by Merck) in $970 \mathrm{~g}$ deionized water (max. conductivity of $0.5 \mathrm{mSm}-1)$ at $20{ }^{\circ} \mathrm{C}$, in accordance with EN 12390-11 [24]. The 3\% $\mathrm{NaCl}+\mathrm{KOH}$ solution was prepared by making the $\mathrm{KOH}$ solution first and then adding the $\mathrm{NaCl}$. The potassium content in the CEM II/C-M (S-LL) pore solution was modelled using the Gibbs free energy minimization software GEMS [32, 33], giving a concentration of $150 \mathrm{mMol} /$ 
Table 4 Overview of number of cylinders and test specimens for $\mu$ XRF scanning and profile grinding prepared for each sample type, exposure solution and exposure time

\begin{tabular}{|c|c|c|c|c|c|}
\hline $\begin{array}{l}\text { Sample } \\
\text { type }\end{array}$ & Exposure solution & $\begin{array}{l}\text { Exposure } \\
\text { time [days] }\end{array}$ & $\begin{array}{l}\text { Number of cylinders/ } \\
\text { test specimens }\end{array}$ & $\begin{array}{l}\text { Test specimen for } \\
\mu X R F \text { scanning }\end{array}$ & $\begin{array}{l}\text { Test specimen for } \\
\text { profile grinding }\end{array}$ \\
\hline Mortar & $3 \% \mathrm{NaCl}$ & 90 & 2 & $*$ & 1 \\
\hline Mortar & $3 \% \mathrm{NaCl}$ & 180 & 2 & 1 & 1 \\
\hline Mortar & $3 \% \mathrm{NaCl}+\mathrm{KOH}$ & 90 & 2 & $*$ & 1 \\
\hline Mortar & $3 \% \mathrm{NaCl}+\mathrm{KOH}$ & 180 & 2 & 1 & 1 \\
\hline Concrete & $3 \% \mathrm{NaCl}$ & 90 & 2 & $*$ & 1 \\
\hline Concrete & $3 \% \mathrm{NaCl}$ & 180 & 2 & 1 & 1 \\
\hline Concrete & $3 \% \mathrm{NaCl}+\mathrm{KOH}$ & 90 & 2 & $*$ & 1 \\
\hline \multirow[t]{2}{*}{ Concrete } & $3 \% \mathrm{NaCl}+\mathrm{KOH}$ & 180 & 2 & 1 & 1 \\
\hline & & SUM & 16 & 4 & 8 \\
\hline
\end{tabular}

* Specimens prepared, results not shown here

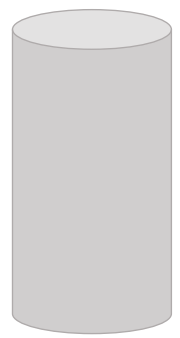

Cylinder

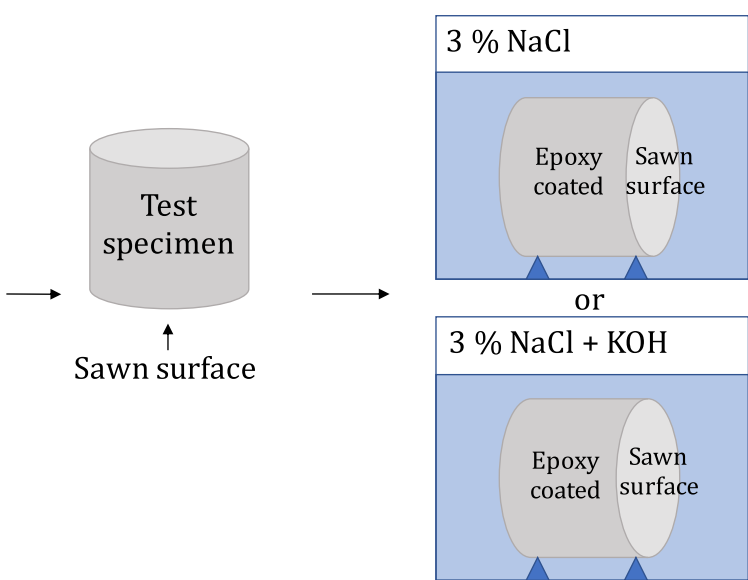

Sealed boxes, $20^{\circ} \mathrm{C}$,

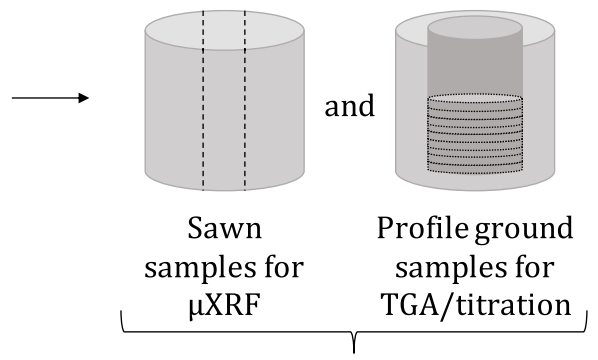

Twin specimens twin specimens for each exposure

Fig. 1 Test specimen preparation, exposure and preparation for analysis

L after 150 days of hydration. To obtain this $\mathrm{KOH}$ concentration, $8.416 \mathrm{~g}$ analytical grade $\mathrm{KOH}$ (supplied by Merck) was dissolved in $1000 \mathrm{~g}$ deionized water. After preparing the $\mathrm{KOH}$ solution, $30 \mathrm{~g} \mathrm{NaCl}$ was dissolved in $970 \mathrm{~g}$ of the $\mathrm{KOH}$ solution.

\subsection{Sample preparation for analysis}

Twin specimens were prepared for all samples, so that after 90 and 180 days 2 concrete and 2 mortar specimens were taken out of each exposure solution. A $2 \mathrm{~cm}$ thick slice was sawn from one of the twin specimens for scanning with the $\mu \mathrm{XRF}$, while the other twin specimen was profile ground in accordance with EN 12390-11 [24] (see Fig. 1 and Table 4). The test specimens for profile grinding were ground in several steps up to various depths depending on the type of exposure solution and exposure time. The depth of each step was measured to an accuracy of $0.1 \mathrm{~mm}$ and was noted. A detailed list of the profile grinding steps for each specimen can be found in the Appendix. 


\section{5 $\mu$ XRF scanning of sawn samples}

The $\mu$ XRF (micro-X-ray fluorescence) scanning of slices from the test mortar and concrete specimens was carried out to determine the chloride ingress depth visually on the samples exposed for 180 days. The scans were performed using a M4 Tornado $\mu$ XRF from Bruker, equipped with an Ag X-ray tube with a spot size $20 \mu \mathrm{m}$, and an SD detector.

Detailed scans were obtained from the exposed surface to approximately $15 \mathrm{~mm}$ inwards on each sawn sample. The distance between the measuring points was set to $25 \mu \mathrm{m}$, with a measuring time of $3 \mathrm{~ms} /$ point. The $\mathrm{X}$-ray tube was operated at $50 \mathrm{kV}$ and $600 \mu \mathrm{A}$ with a vacuum at $20 \mathrm{mbar}$. The scans provided a qualitative description of the spaceresolved presence of various elements from the exposed surface inwards, presented as elemental maps. Chlorine maps were obtained for all sawn samples.

\subsection{Determination of chloride profiles for profile ground samples}

From each profile ground section, approx. $5 \mathrm{~g}$ of powder was weighed into glass beakers, dried overnight at $105{ }^{\circ} \mathrm{C}$, and weighed again after drying to determine the dry weight of each section. The dried powder was dissolved in $50 \mathrm{~mL} \mathrm{HNO}_{3}(65 \%$, diluted 1:10), which was heated to $80^{\circ} \mathrm{C}$. The slurry was filtrated after $1 \mathrm{~h}$. The chloride content in the resulting filtrate was determined by potentiometric titration against a $0.01 \mathrm{~mol} / \mathrm{L} \quad \mathrm{AgNO}_{3}$ solution using a Metrohm Titrando 905 titrator. The chloride content as $w t \%$ of the ground concrete or mortar sections dried at $105{ }^{\circ} \mathrm{C}$ was calculated using Eq. 1 .

$\left.\mathrm{Cl} \%=\frac{V_{\mathrm{AgNO}_{3}} \cdot c_{\mathrm{AgNO}_{3}} \cdot M(\mathrm{Cl}) \cdot V_{\mathrm{HNO}_{3}} \cdot 0.001}{V_{\text {sample }} \cdot m_{\text {concrete }} / \text { mortar,dried }}\right) 100$

$V_{\mathrm{AgNO}_{3}}$ and $c_{\mathrm{AgNO}_{3}}$ represent the volume $[\mathrm{mL}]$ and concentration of the $\mathrm{AgNO}_{3}$ solution $(0.01 \mathrm{~mol} / \mathrm{L})$. $\mathrm{M}(\mathrm{Cl})$ is the molar mass of chlorine $(35.45 \mathrm{~g} / \mathrm{mol})$. $V_{\mathrm{HNO}_{3}}$ is the volume of diluted $\mathrm{HNO}_{3}$ used to dissolve the profile ground and dried sample $(50 \mathrm{~mL}) . V_{\text {sample }}$ is the volume of the dissolved and filtered sample used for the titration $(1-10 \mathrm{~mL})$, and $m_{\text {concrete/mortar,dried }}$ is the mass of profile ground sample dried at $105{ }^{\circ} \mathrm{C}$.
Single determinations on each section were performed, so no margin of error in the determination of the total chloride content could be calculated. However, since the analyses were performed at different depths from the exposed surface in each specimen, a gradual change in the total chloride content would be expected, allowing outliers to be identified. To estimate the margin of error in the determinations of the chloride content in this study, we used the average standard deviation values for chloride content measurements reported by De Weerdt et al. [13], who followed the same experimental procedure as described in this study. The estimated margin of error ( $0.03 \mathrm{wt} \% \mathrm{Cl}$ of sample dried at $105{ }^{\circ} \mathrm{C}$ [13]) is shown with error bars in Fig. 4.

\subsection{Determination of portlandite profiles} on profile ground specimens

To investigate the degree of leaching in the specimens, portlandite $\left(\mathrm{Ca}(\mathrm{OH})_{2}\right)$ profiles were obtained from the profile ground samples using thermogravimetric analysis (TGA). The TGA measurements were performed using a Mettler Toledo TGA/DSC 3+ on homogenized profile ground samples from each mortar or concrete specimen. Approximately $300 \mathrm{mg}$ from each section was poured into $600 \mu \mathrm{L}$ corundum crucibles. The samples were heated from $40{ }^{\circ} \mathrm{C}$ to $900{ }^{\circ} \mathrm{C}$ at a rate of $10{ }^{\circ} \mathrm{C} / \mathrm{min}$, while the oven was purged with $50 \mathrm{~mL} / \mathrm{min}_{2}$. The sample weight was monitored as a function of the temperature (TG-curves). The decomposition of portlandite takes place between approximately $400{ }^{\circ} \mathrm{C}$ and $500{ }^{\circ} \mathrm{C}$. The mass loss due to the decomposition of the portlandite was determined by integration of the derivative of the TG-curve (DTG) as described in Lothenbach et al. [34]. The portlandite content normalized to the dry sample weight was calculated using Eq. 2, where $w_{400}-w_{500}$ represents the mass loss due to the decomposition of portlandite, $w_{550}$ represents the dry sample weight at $550{ }^{\circ} \mathrm{C}$, and $\mathrm{M}\left(\mathrm{Ca}(\mathrm{OH})_{2}\right)$ and $\mathrm{M}\left(\mathrm{H}_{2} \mathrm{O}\right)$ are the molar masses of portlandite $(74 \mathrm{~g} / \mathrm{mol})$ and water $(18 \mathrm{~g} / \mathrm{mol})$ respectively. It should be noted that, for samples in which the carbonate weight loss started before $550{ }^{\circ} \mathrm{C}$, the results were normalized to the sample weight at the temperature just before decomposition of the carbonates started. 


$$
\begin{aligned}
& \mathrm{Ca}(\mathrm{OH})_{2}[\mathrm{wt} \% / g \text { dry sample }] \\
& =\frac{w_{400}-w_{500}}{w_{550}} \cdot \frac{M\left(\mathrm{Ca}(\mathrm{OH})_{2}\right)}{M\left(\mathrm{H}_{2} \mathrm{O}\right)}
\end{aligned}
$$

In this study, the reduction in the portlandite content in the concrete or mortar specimens was used as an indicator for leaching.

It should be noted that when a sample is leached, it loses mass as solid phases dissolve. In the case of Eq. 2, this would mean that $w_{550}$ would decrease due to leaching. If $w_{550}$ decreases, we divide the $w_{400}-w_{500}$ mass difference in Eq. 2 by a smaller number, and would thereby artificially increase the amount of $\mathrm{Ca}(\mathrm{OH})_{2}$ expressed as [wt\%/g dry sample]. We may therefore slightly overestimate the portlandite content in the leached sections. In Machner et al. [26] and Hemstad et al. [19] a method to compensate for the mass loss due to leaching is proposed, but this requires XRF analysis of the sections or ICP-MS analysis of the acid dissolved sections, which were not available in the current study.

Single determinations of the portlandite content were performed on each section, so no margin of error in the portlandite content determination could be calculated for each section. However, since the analyses were performed at different depths from the exposed surface in each specimen, a gradual change in the portlandite content would be expected, allowing outliers to be identified. In order to estimate the margin of error in the portlandite quantification in this study, we calculated the standard deviations of the portlandite content in the sections that show the background level in each specimen. The standard deviations calculated for the various samples ranged between 0.01 and $0.04 \mathrm{wt} \% \mathrm{Ca}(\mathrm{OH})_{2} / \mathrm{g}$ of dry sample, which are values similar to previously reported standard deviations obtained for portlandite profiles determined using TGA [35]. These values are shown with error bars in Fig. 2.

\section{Results}

\subsection{Portlandite profiles from TGA}

Figure 2(a) and (b) show the portlandite $\left(\mathrm{Ca}(\mathrm{OH})_{2}\right)$ content in the various profile ground sections as a function of the depth from the exposed surface for the mortar and concrete specimens respectively. The depth values correspond to the centre of each profile grinding step. A selection of DTG-curves and the tabulated results of the portlandite quantification can be found in the Appendix.

The sections analysed show a near constant portlandite content at greater depths. These values represent the background portlandite content of the unaltered sections. The background level is independent of the exposure solution. The portlandite background level for the concrete (ca. $0.6 \mathrm{wt} \%$ ) is considerably lower than for the mortar (ca. 1.2 $\mathrm{wt} \%$ ). This is expected because concrete contains less cement relative to the total mass than mortar does (see Table 2).

The specimens exposed to the $\mathrm{NaCl}$ solution show a clear decrease in portlandite content in the sections closer to the exposed surface until no portlandite is present in the outermost section of these specimens. The portlandite content in the specimens exposed to the $\mathrm{NaCl}+\mathrm{KOH}$ solution also decreases towards the exposed surface, but to a considerably lesser degree than the specimens exposed to the $\mathrm{NaCl}$ solution. This indicates that, for both mortar and concrete specimens, our experimental set-up promoted leaching in the case of exposure to the $\mathrm{NaCl}$ solution and limited leaching in the case of exposure to the $\mathrm{NaCl}+\mathrm{KOH}$ solution.

With time, portlandite continued to leach from all the specimens that were exposed to the $\mathrm{NaCl}$ solution, but this was especially clear in the case of the concrete specimens. In contrast, the leaching of portlandite in both mortar and concrete specimens exposed to the $\mathrm{NaCl}+\mathrm{KOH}$ solution seemed to stagnate in the period from 90 to 180 days of exposure.

It should be noted that the mortar and concrete specimens might have been exposed to some slight surface carbonation during the sample preparation, specifically during the drying of the epoxy coating. This might lead to a reduction in the portlandite content in the outermost section as also observed in [13], prior to exposure. During the submerged exposure, carbonation progresses very slowly, and will therefore not affect the portlandite profiles, within the investigated time range.

\subsection{Chlorine maps from $\mu \mathrm{XRF}$ scanning}

Figure 3 shows chlorine maps obtained by $\mu \mathrm{XRF}$ scanning of sawn samples from the mortar and concrete specimens exposed for 180 days to the $\mathrm{NaCl}$ 
Fig. 2 Portlandite $\left(\mathrm{Ca}(\mathrm{OH})_{2}\right)$ profiles obtained from TGA for (a) mortar and (b) concrete specimens exposed to $\mathrm{NaCl}$ (solid lines) and $\mathrm{NaCl}+\mathrm{KOH}$ (dashed lines) for 90 days (filled symbols) and 180 days (hollow symbols)

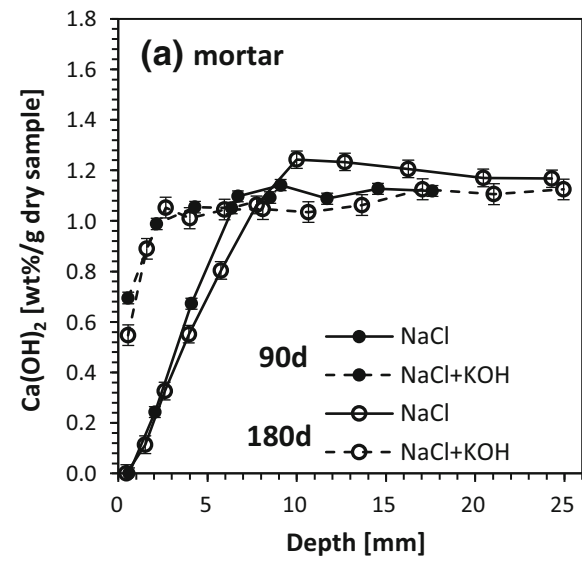

solution (left) and the $\mathrm{NaCl}+\mathrm{KOH}$ solution (right). In Fig. 3, the bottom of the maps represents the surface exposed to the chloride solutions. The results presented give a qualitative illustration of the ingress of the chloride from the exposed surface inwards. The level of chloride detected in the area close to the exposed surface is much higher in the case of exposure to the $\mathrm{NaCl}$ solution than in the case of exposure to the $\mathrm{NaCl}+\mathrm{KOH}$ solution for both mortar and concrete. This indicates a higher chloride ingress in the specimens exposed to $\mathrm{NaCl}$ solution than in those exposed to $\mathrm{NaCl}+\mathrm{KOH}$ solution, even though both solutions have a similar chloride concentration.

\subsection{Total chloride profiles}

Figure 4 presents the total chloride content as a function of the depth from the exposed surface for all the specimens as determined by potentiometric titration. The depth values of the data points

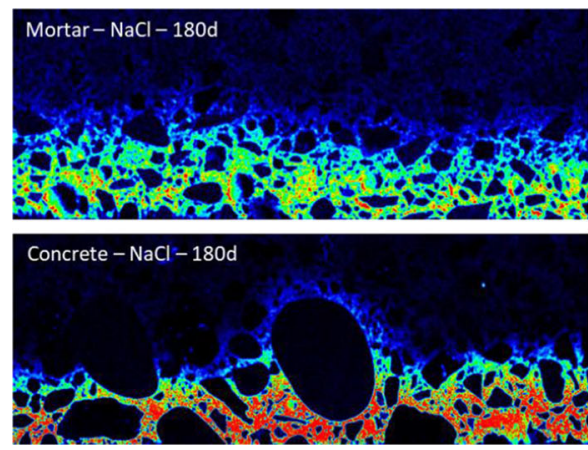

Fig. 3 Chlorine heat maps from $\mu \mathrm{XRF}$ scans for sawn mortar and concrete samples exposed to $\mathrm{NaCl}$ (left) or $\mathrm{NaCl}+\mathrm{KOH}$ (right) for 180 days. The bottom surface was exposed to the correspond to the centre of each profile-grinding step. The results of each determination are also tabulated in the Appendix.

The specimens exposed to the $\mathrm{NaCl}$ solution showed as much as three times higher chloride content than the corresponding specimens exposed to the $\mathrm{NaCl}+\mathrm{KOH}$ solution. The total chloride content after exposure to the $\mathrm{NaCl}$ solution also seemed to increase with time, whereas it remained largely unchanged in the case of $\mathrm{NaCl}+\mathrm{KOH}$ exposure for 90 and 180 days. As expected, the mortar specimens showed a higher chloride content than the corresponding concrete specimens in all cases. This is because mortar has a higher cement content than concrete (see Table 2), which gives mortar specimens a higher chloride-binding capacity than concrete specimens in terms of wt $\%$ per g sample. It should also be noted that the chloride content of the outermost section of the specimens exposed to the $\mathrm{NaCl}$ solution showed a lower chloride content than the sections slightly

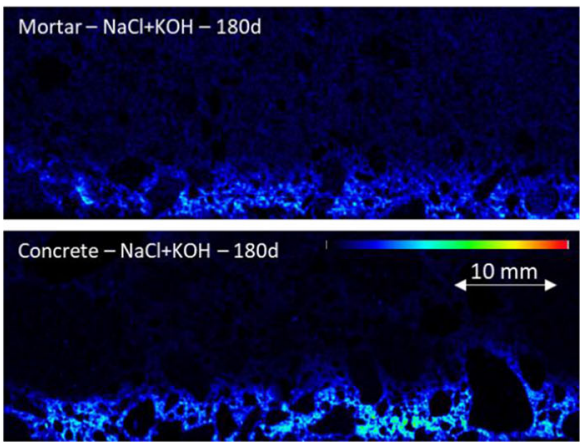

chloride solutions in all sawn samples. Dark blue indicates low levels of chlorine, while red indicates high levels 


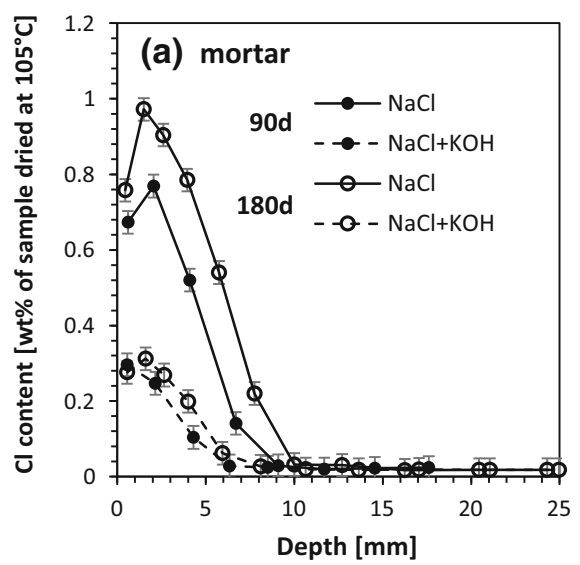

Fig. 4 Total chloride content as a function of the depth from the exposed surface for (a) mortar and (b) concrete specimens. The specimens were exposed to $\mathrm{NaCl}$ (solid lines) or $\mathrm{NaCl}+\mathrm{KOH}$

deeper in. This phenomenon is commonly referred to as "peaking behaviour". The only exception from this is the concrete specimen exposed for only 90 days to the $\mathrm{NaCl}$ solution.

The chloride ingress depth was also considerably greater in the specimens exposed to the $\mathrm{NaCl}$ solution than for those exposed to the $\mathrm{NaCl}+\mathrm{KOH}$ solution, and it increased with time, whereas the ingress seemed to stagnate in the specimens exposed to $\mathrm{NaCl}+\mathrm{KOH}$.

\section{Discussion}

\subsection{Correlation of leaching depth and chloride ingress depth}

Figure 5 compares the chloride profiles (see Fig. 4) and the portlandite $\left(\mathrm{Ca}(\mathrm{OH})_{2}\right)$ profiles (see Fig. 2) determined on the same profile ground sections of mortar or concrete specimens exposed to $\mathrm{NaCl}$ or $\mathrm{NaCl}+\mathrm{KOH}$ solutions for 90 and 180 days. The results from Figs. 4 and 2 are combined in Fig. 5 to illustrate the correlation between chloride ingress and leaching. The portlandite content is considered as an inverse indicator of the extent of leaching, i.e. the greater the decrease in portlandite content, the higher the degree of leaching.

In the mortar and concrete specimens exposed to the $\mathrm{NaCl}$ solution (solid lines), the depths at which we observed a decrease in the portlandite content correspond to the depths at which we observed chloride

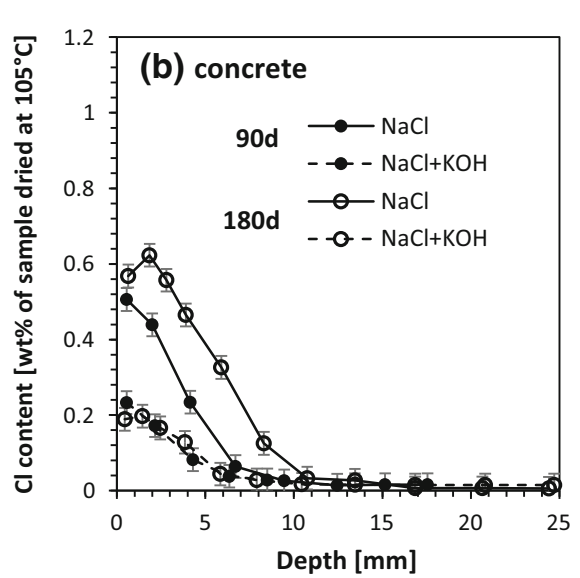

(dashed lines) for 90 days (filled symbols) and 180 days (hollow symbols)

ingress after both 90 and 180 days of exposure. However, in the specimens exposed to $\mathrm{NaCl}+\mathrm{KOH}$ (dashed lines), this correlation between the depth of chloride ingress and leaching was not as clear, as chlorides seem to penetrate slightly deeper than the leached depth. The findings indicate that leaching and chloride ingress are related: limiting leaching can limit chloride ingress, and promoting leaching can promote chloride ingress. However, there is no unique correlation between the chloride ingress depth and the leaching depth.

Exactly how leaching affects chloride ingress depth needs further investigation. As part of the EnDurCrete project, we plan to explain this by simulating chloride ingress in a multi-ion model that includes various ingress mechanisms and takes leaching into account [36].

\subsection{Impact of leaching on the total chloride content}

The total chloride content seems to be related to the extent of leaching. The portlandite content of specimens exposed to the $\mathrm{NaCl}$ solution was considerably reduced towards the exposed surface, indicating advanced leaching. In these leached sections, we measured higher total chloride contents (see Fig. 5). In the case of $\mathrm{NaCl}+\mathrm{KOH}$ exposure, the portlandite levels decreased to a much smaller extent towards the exposed surface, indicating limited leaching. These specimens had considerably lower total chloride 
Fig. 5 Comparison of chloride profiles (black) and portlandite $\left(\mathrm{Ca}(\mathrm{OH})_{2}\right)$ profiles (grey) of mortar specimens (a and b) and concrete specimens (c and d) exposed to $\mathrm{NaCl}$ (solid lines) and $\mathrm{NaCl}+\mathrm{KOH}$ (dashed lines), for 90 days (filled symbols) and 180 days (hollow symbols)
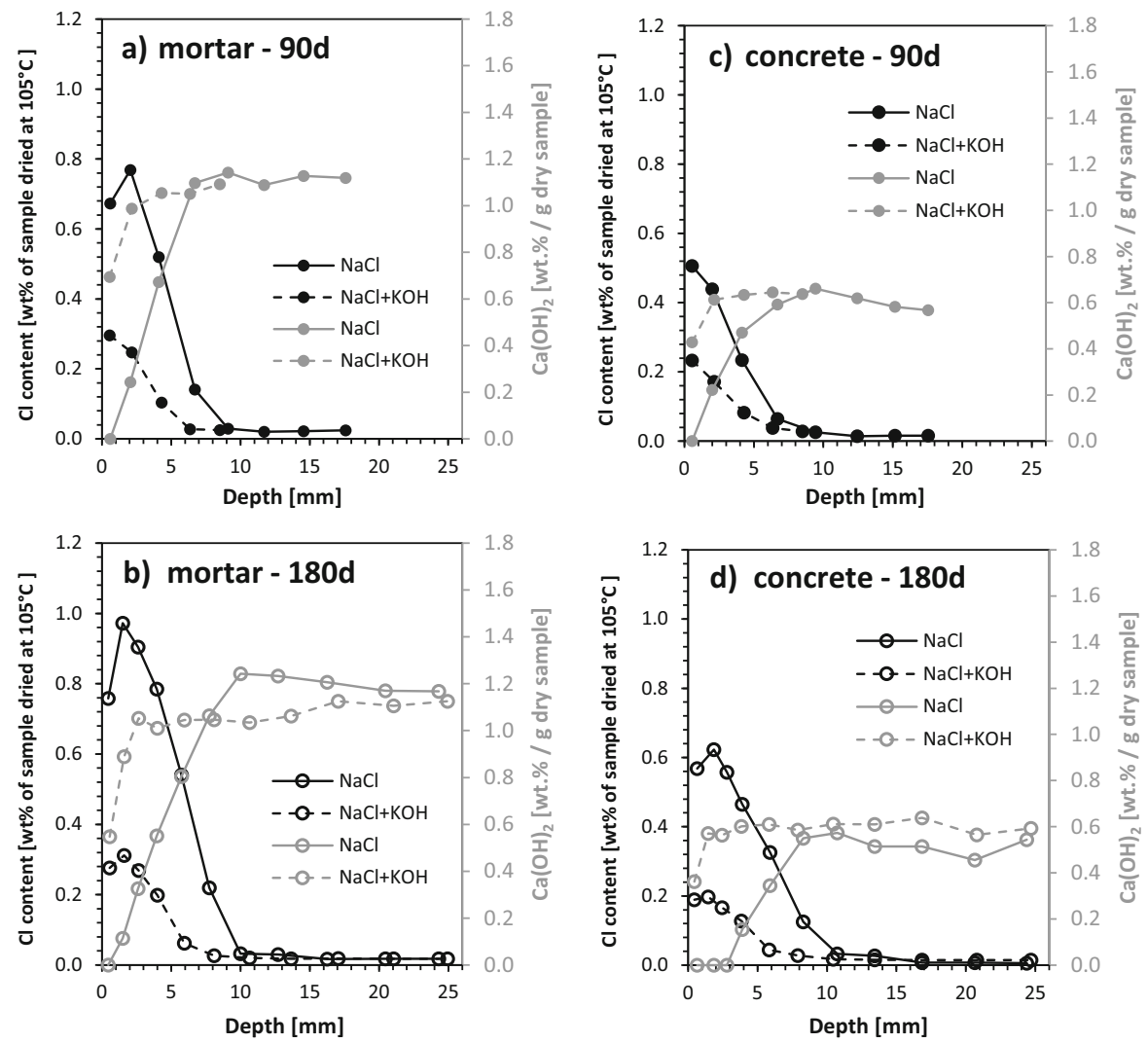

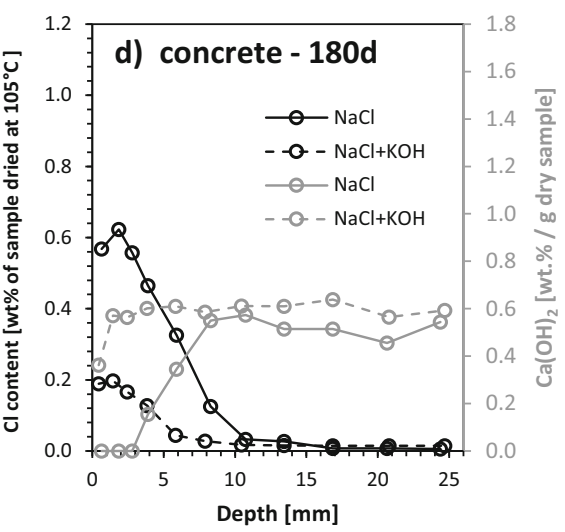

contents than the more leached specimens exposed to the $\mathrm{NaCl}$ solution.

We attribute the approx. 3 times higher chloride content in the more severely leached specimens to an increased binding capacity of the cement paste upon leaching. A recent study [19] demonstrated that chloride binding increases when the $\mathrm{pH}$ in the exposure solution in equilibrium with the solids is reduced from 13 to 12 . The increased binding capacity was attributed to an increased uptake of chlorides by AFm phases as well as adsorption onto the $\mathrm{C}-\mathrm{S}-\mathrm{H}$. A correlation between chloride-binding capacity and the $\mathrm{pH}$ of the exposure solution has already been postulated previously [2, 6, 17, 37, 38]. However, Hemstad et al. [19] found that when the $\mathrm{pH}$ of the exposure solution in equilibrium with the solids drops below 12 , the chloride-binding capacity of the paste drastically decreases because the hydrates binding the chlorides start to decompose. The point where the $\mathrm{pH}$ of the pore solution drops below $12 / 12.5$ is commonly related to the point where all portlandite has been dissolved, because portlandite acts as a $\mathrm{pH}$ buffer to maintain a
$\mathrm{pH}$ of approx. 12.5 in the pore solution. This explains the observed reduction in the total chloride content in the outermost section of the specimens exposed to $\mathrm{NaCl}$, because this section no longer contained any portlandite and was therefore heavily leached and had lost part of its binding capacity. This might cause the "peaking-behaviour" in specimens exposed to the $\mathrm{NaCl}$ solution.

It should be noted that composite cements containing various SCMs create pore solutions with different $\mathrm{pH}$ values and buffer capacities, due to differences in the amount of alkalis or portlandite present in the hydrated binders. The concept described here might therefore vary depending on the buffer capacity of the binders investigated. Further research is needed to verify this concept with different binders.

Note too that in the specimens exposed to the $\mathrm{NaCl}$ solution, the total chloride content close to the exposed surface increased with time. This has also been observed in field samples, and in some cases has been described as a time-dependent surface concentration [18]. Based on the findings presented in this paper, we 
can attribute this time-dependent increase to an increase in leaching with time. Figure 2 shows a decrease in the portlandite content from 90 to 180 days in the sections to a depth of as much as $10 \mathrm{~mm}$, which indicates advanced leaching and therefore an increase in the chloride-binding capacity of the hydration phases with time.

It should further be noted that leaching also increases the porosity and permeability of the cement paste and this will also affect the chloride ingress and chloride profiles [39]. Upon leaching, the first hydrate to dissolve is portlandite [26, 27]. The dissolution of portlandite leads to an increase in porosity. In the case of our mortar specimens, which had a portlandite background content of $1.2 \mathrm{wt} \%$ per dry sample mass $\left(1.08 \mathrm{wt} \%\right.$ per sample mass at $105{ }^{\circ} \mathrm{C}$ ), the complete dissolution of the portlandite would lead to an increase in pore volume of $0.45 \mathrm{~mL}$ per $100 \mathrm{~g}$ of sample dried at $105{ }^{\circ} \mathrm{C}$ (taking into account the molar mass of $74 \mathrm{~g} / \mathrm{mol}$ and molar volume $33 \mathrm{~mL} / \mathrm{mol}$ of portlandite). If we assume the worst-case scenario, meaning that this additional porosity was filled with the same chloride concentration as the exposure solution (3\% $\mathrm{NaCl}$ solution with a density of $1.02 \mathrm{~g} / \mathrm{mL}$ ), this would represent an additional $0.009 \mathrm{wt} \%$ chloride per mass of mortar dried at $105^{\circ} \mathrm{C}$. This means an increase in the chloride content in the mortar of $3 \%$ compared to the maximum total chloride content measured for the mortar exposed to $\mathrm{NaCl}+\mathrm{KOH}$ independent of the exposure time (see Fig. 4). The difference in total chloride content with and without leaching approximated to a factor of 3 or $300 \%$. This means that the increase in the total chloride content upon advanced leaching must have been mainly due to enhanced chloride-binding caused by leaching.

\subsection{Impact on standard laboratory testing and service life modelling}

Together, the chloride ingress depth and the maximum total chloride content determine the shape of a total chloride profile. The results in this study demonstrate that the shape of the total chloride profiles obtained very much depends on the leaching conditions during the exposure. As such profiles are used for the prediction of service life, the leaching conditions during the exposure of mortar or concrete test specimens have a considerable impact on such estimates. From the experimentally obtained data after 180 days of exposure in this study, we determined the service life for the mortar and concrete specimens exposed to the two different solutions in accordance with Annex B2 in fib Bulletin 34 [12], assuming a time independent diffusion coefficient, a critical chloride content of $0.6 \mathrm{wt} \% / \mathrm{g}$ cement (yielding a critical chloride content of $0.15 \mathrm{wt} \% / \mathrm{g}$ mortar dried at $105^{\circ} \mathrm{C}$ ) as recommended in fib Bulletin 34 [12] and a concrete cover depth of $50 \mathrm{~mm}$ in accordance with Eurocode 2 [40]. A service life of approx. 10 years was calculated for the specimens exposed to the $\mathrm{NaCl}$ solution, while for the specimens exposed to the $\mathrm{NaCl}+\mathrm{KOH}$ solution a service life of approx. 60 years was calculated. The detailed description and data on the service life prediction can be found in the electronic supplementary material for this paper (see Online Resource 1).

This difference in the predicted service life resulting from the leaching conditions during exposure becomes very important when laboratory testing is used to predict the service life of structures in e.g. marine conditions. In the laboratory, the leaching conditions are commonly drastically reduced compared to e.g. exposure to the sea, which is an unlimited reservoir of leachate. If neither the leaching conditions during exposure nor the degree of leaching of the samples after a given exposure time are taken into account, the service life or performance determined by empirical models might be misleading. A sample that under limited leaching conditions in the lab showed reasonably good resistance to chloride ingress can fail to withstand chloride ingress once it is placed out in the sea, where it is exposed to considerably harsher leaching conditions.

This potential difference in predicted service life based on the total chloride profiles obtained during laboratory testing shows the importance of taking leaching into account during laboratory testing, such as [20-24]. This can be done by having reproducible procedures for the test, e.g. sufficiently high ratios between the volume of the exposure solution and the exposed surface, and routines for regularly replacing the exposure solution.

In addition, one might question whether models that fit ingress profiles to the total chloride content profiles are a good approach to start with. The total chloride content is merely a reflection of the potential of the solids to take up chlorides and, as demonstrated in this study, is strongly dependent on leaching. One should see the chloride content as an indicator for how 
far the chlorides have penetrated the concrete, but not necessarily as the potential for ingress as done by many models. A good illustration of this is that the chloride content at the surface of submerged concrete becomes slightly lower with time than the chloride content a few $\mathrm{mm}$ or $\mathrm{cm}$ deeper in - the so-called "peaking-behaviour". This means the total chloride content at the surface cannot be the driving force for the ingress. We should focus on ingress depth rather than on fitting total chloride content profiles [41].

This calls for more mechanistic models such as [38, 42-49]. If we want to verify chloride ingress using total chloride content profiles, we need to take account of the various exposure conditions, interactions between the solids and chlorides, their dependency on leaching, binder composition, and time.

\section{Conclusions}

In order to investigate the effect of leaching on chloride ingress profiles, concrete and mortar specimens were exposed for 90 and 180 days to two different exposure solutions: $3 \% \mathrm{NaCl}$, and $3 \% \mathrm{NaCl}$ with additional $\mathrm{KOH}$ to limit leaching. After exposure, total chloride profiles were determined, as well as portlandite profiles to investigate the extent of leaching.

- The experimental setup of the two exposure solutions enabled us to produce considerably different extents of leaching with the same chloride load. The portlandite profiles showed that exposure to the $\mathrm{NaCl}$ solution led to extensive leaching, whereas with exposure to $\mathrm{NaCl}+\mathrm{KOH}$, leaching was limited.

- The specimens exposed to the $\mathrm{NaCl}$ solution also showed a considerably higher chloride ingress depth than those exposed to the $\mathrm{NaCl}+\mathrm{KOH}$ with limited leaching. This indicates that one can promote chloride ingress by leaching and hinder chloride ingress by limiting leaching.

- In this study, exposure to the $\mathrm{NaCl}$ solution led to maximum total chloride contents about 3 times higher than exposure to the $\mathrm{NaCl}+\mathrm{KOH}$ solution even though the chloride load was the same. This indicates that leaching greatly affects the interaction between solids and chlorides. The enhanced leaching in the samples exposed to the $\mathrm{NaCl}$ solution might also explain the "peaking- behaviour" typically observed in long-term exposed field samples.

- These findings show how important it is to take leaching into account when performing standard laboratory testing. Leaching should also be taken into account in service life prediction, e.g. by the use of more mechanistic chloride ingress models.

\section{Limitations and further research}

The impact of leaching during exposure on total chloride profiles was demonstrated on one Portland composite cement, which contains ground granulated blast furnace slag and limestone. Plain Portland cement, and other composite cements containing different SCMs, would need to be tested as well to fully verify the concept demonstrated in this study. Different SCMs may considerably affect the $\mathrm{pH}$ buffer capacity and the chloride-binding capacity of the binder, and thereby the total chloride profiles.

In a follow-up study we will investigate the changes in the phase assemblage and the composition of the hydration phases (e.g. AFm and $\mathrm{C}-(\mathrm{A})-\mathrm{S}-\mathrm{H}$ ) in mortar samples exposed to $\mathrm{NaCl}$ and $\mathrm{NaCl}+\mathrm{KOH}$ for 180 day in detail using a range of experimental techniques combined with thermodynamic modelling. The focus of the follow-up study is to document how chloride binding in the hydration phases changes under different leaching conditions, and how this relates to the shape of the total chloride profiles.

Acknowledgements The authors would like to thank the EnDurCrete project partner Rosa Marie Carreras Lample from Acciona for preparing the samples for this study. In addition, we would like to thank Sebastijan Robič from ZAG for help with the specimen exposure and profile grinding, Siri Hofstad Trapnes from SINTEF, and Tone H. Nilsen and Oda Tjetland from NTNU for their help with the chloride titration and TGA measurements, Syverin Lierhagen from NTNU for the ICP-MS analyses, and Petter Hemstad from NTNU for assistance and training for the $\mu \mathrm{XRF}$. The authors would also like to acknowledge the helpful discussions with Lucija Hanžič from ZAG and Mette R. Geiker from NTNU.

Funding Open Access funding enabled and organized by Projekt DEAL. This project has received funding from the European Union's Horizon 2020 research and innovation programme under grant agreement No 760639 and this publication reflects only the authors' view and the Commission is not responsible for any use that may be made of the information it contains. 


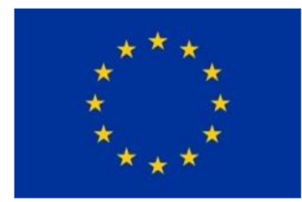

\section{Declarations}

Conflict of interest The authors declare that they have no conflict of interest.

Open Access This article is licensed under a Creative Commons Attribution 4.0 International License, which permits use, sharing, adaptation, distribution and reproduction in any medium or format, as long as you give appropriate credit to the original author(s) and the source, provide a link to the Creative Commons licence, and indicate if changes were made. The images or other third party material in this article are included in the article's Creative Commons licence, unless indicated otherwise in a credit line to the material. If material is not included in the article's Creative Commons licence and your intended use is not permitted by statutory regulation or exceeds the permitted use, you will need to obtain permission directly from the copyright holder. To view a copy of this licence, visit http://creativecommons.org/licenses/by/4.0/.

\section{Appendix}

See Figs. 6, 7 and Table 5
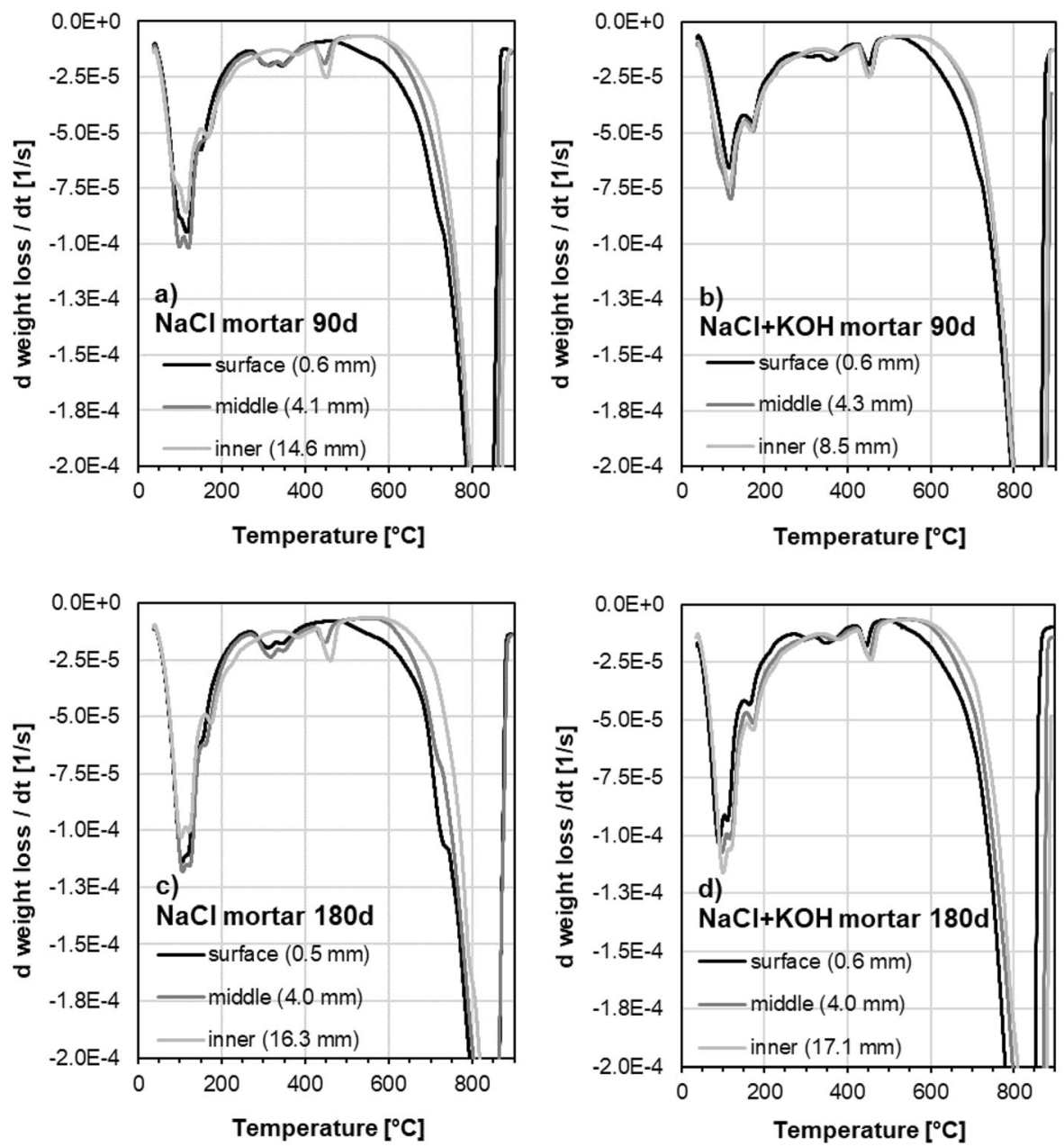

Fig. 6 Selection of DTG curves from surface, middle and inner sections (average depth of each section is specified between brackets) of the investigated mortar samples after 90 or 180 days of exposure to either the $\mathrm{NaCl}$ or the $\mathrm{NaCl}+\mathrm{KOH}$ solution 

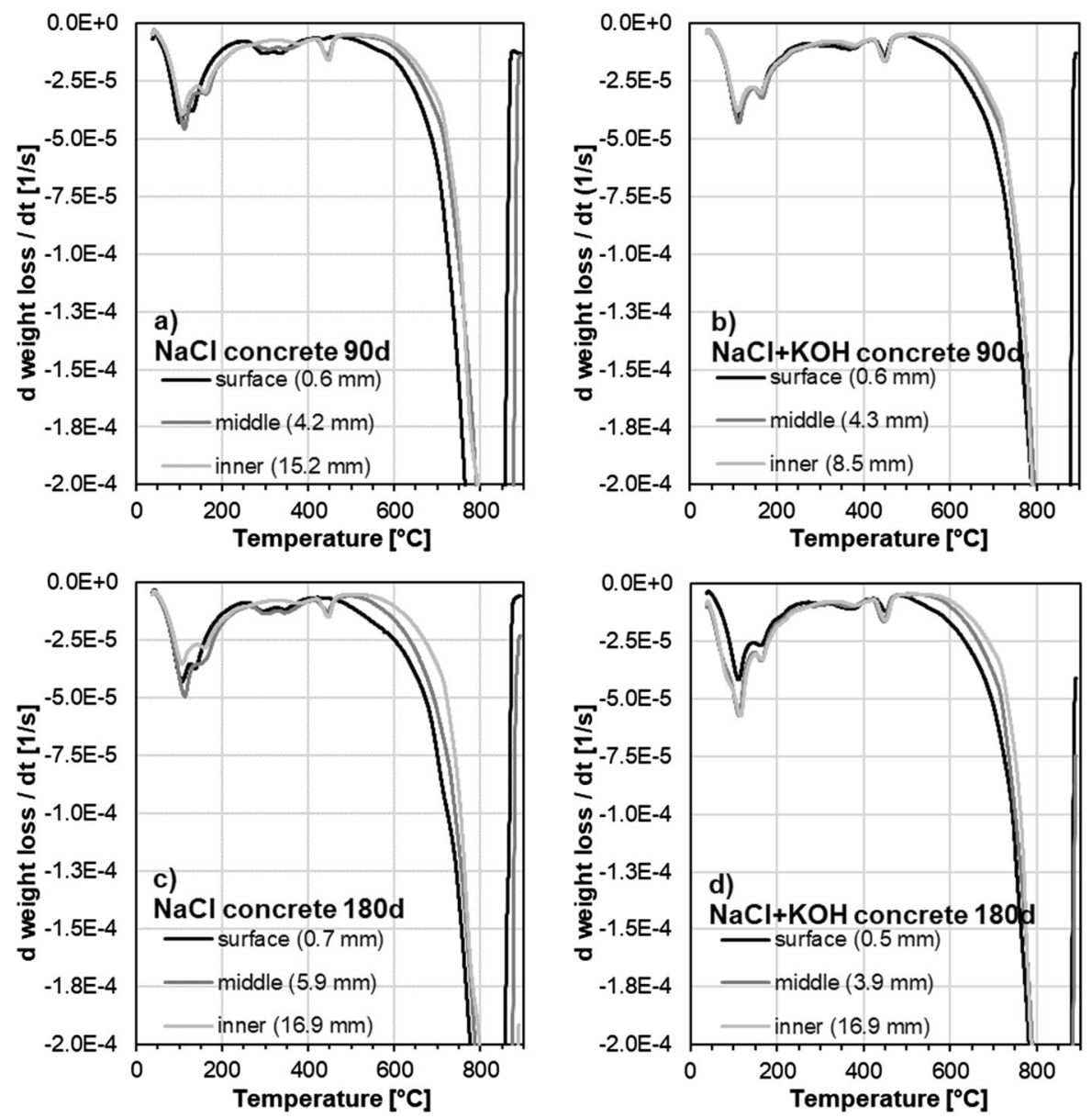

Fig. 7 Selection of DTG curves from surface, middle and inner sections (average depth of each section is specified between brackets) of the investigated concrete samples after 90 or 180 days of exposure to either the $\mathrm{NaCl}$ or the $\mathrm{NaCl}+\mathrm{KOH}$ solution 
Table 5 Profile grinding steps, portlandite $\left(\mathrm{Ca}(\mathrm{OH})_{2}\right)$ and chloride $(\mathrm{Cl})$ content for all specimens analysed in this study

\begin{tabular}{|c|c|c|c|c|c|c|c|c|c|}
\hline \multicolumn{5}{|c|}{$\mathrm{NaCl}$ Mortar 90d } & \multicolumn{5}{|c|}{$\mathrm{NaCl}$ Mortar $180 \mathrm{~d}$} \\
\hline $\begin{array}{l}\text { Start } \\
{[\mathrm{mm}]}\end{array}$ & $\begin{array}{l}\text { End } \\
{[\mathrm{mm}]}\end{array}$ & $\begin{array}{l}\text { Average } \\
\text { Depth } \\
{[\mathrm{mm}]}\end{array}$ & $\begin{array}{l}\mathrm{Ca}(\mathrm{OH})_{2}[\mathrm{wt} \% / \\
\mathrm{g} \text { dry sample] }\end{array}$ & $\begin{array}{l}\mathrm{Cl} \text { cont. }[\mathrm{wt} \% / \mathrm{g} \\
\left.\text { sample } 105^{\circ} \mathrm{C}\right]\end{array}$ & $\begin{array}{l}\text { Start } \\
{[\mathrm{mm}]}\end{array}$ & $\begin{array}{l}\text { End } \\
{[\mathrm{mm}]}\end{array}$ & $\begin{array}{l}\text { Average } \\
\text { Depth } \\
{[\mathrm{mm}]}\end{array}$ & $\begin{array}{l}\mathrm{Ca}(\mathrm{OH})_{2} \\
{[\mathrm{wt} \% / \mathrm{g} \text { dry }} \\
\text { sample] }\end{array}$ & $\begin{array}{l}\mathrm{Cl} \text { cont. [wt } \% / \mathrm{g} \\
\left.\text { sample } 105^{\circ} \mathrm{C}\right]\end{array}$ \\
\hline 0 & 1.2 & 0.6 & 0.00 & 0.67 & 0 & 0.9 & 0.5 & 0.00 & 0.76 \\
\hline 1.2 & 2.9 & 2.1 & 0.24 & 0.77 & 0.9 & 2.1 & 1.5 & 0.11 & 0.97 \\
\hline 2.9 & 5.3 & 4.1 & 0.67 & 0.52 & 2.1 & 3.1 & 2.6 & 0.33 & 0.90 \\
\hline 5.3 & 8.1 & 6.7 & 1.10 & 0.14 & 3.1 & 4.8 & 4.0 & 0.55 & 0.79 \\
\hline 8.1 & 10.1 & 9.1 & 1.14 & 0.03 & 4.8 & 6.7 & 5.8 & 0.80 & 0.54 \\
\hline 10.1 & 13.3 & 11.7 & 1.09 & 0.02 & 6.7 & 8.8 & 7.8 & 1.06 & 0.22 \\
\hline 13.3 & 15.8 & 14.6 & 1.13 & 0.02 & 8.8 & 11.2 & 10.0 & 1.24 & 0.03 \\
\hline \multirow[t]{4}{*}{15.8} & 19.4 & 17.6 & 1.12 & 0.02 & 11.2 & 14.2 & 12.7 & 1.23 & 0.03 \\
\hline & & & & & 14.2 & 18.3 & 16.3 & 1.21 & 0.02 \\
\hline & & & & & 18.3 & 22.6 & 20.5 & 1.17 & 0.02 \\
\hline & & & & & 22.6 & 26 & 24.3 & 1.17 & 0.02 \\
\hline \multicolumn{5}{|c|}{$\mathrm{NaCl}$ Concrete $90 \mathrm{~d}$} & \multicolumn{5}{|c|}{$\mathrm{NaCl}$ Concrete $180 \mathrm{~d}$} \\
\hline $\begin{array}{l}\text { Start } \\
{[\mathrm{mm}]}\end{array}$ & $\begin{array}{l}\text { End } \\
{[\mathrm{mm}]}\end{array}$ & $\begin{array}{l}\text { Average } \\
\text { Depth } \\
{[\mathrm{mm}]}\end{array}$ & $\begin{array}{l}\mathrm{Ca}(\mathrm{OH})_{2}[\mathrm{wt} \% / \\
\mathrm{g} \text { dry sample] }\end{array}$ & $\begin{array}{l}\mathrm{Cl} \text { cont. }[\mathrm{wt} \% / \mathrm{g} \\
\left.\text { sample } 105^{\circ} \mathrm{C}\right]\end{array}$ & $\begin{array}{l}\text { Start } \\
{[\mathrm{mm}]}\end{array}$ & $\begin{array}{l}\text { End } \\
{[\mathrm{mm}]}\end{array}$ & $\begin{array}{l}\text { Average } \\
\text { Depth } \\
{[\mathrm{mm}]}\end{array}$ & $\begin{array}{l}\mathrm{Ca}(\mathrm{OH})_{2} \\
{[\mathrm{wt} \% / \mathrm{g} \text { dry }} \\
\text { sample] }\end{array}$ & $\begin{array}{l}\mathrm{Cl} \text { cont. [wt } \% / g \\
\text { sample } 105^{\circ} \mathrm{C} \text { ] }\end{array}$ \\
\hline 0 & 1.1 & 0.6 & 0.00 & 0.51 & 0 & 1.3 & 0.7 & 0.00 & 0.57 \\
\hline 1.1 & 2.9 & 2 & 0.22 & 0.44 & 1.3 & 2.4 & 1.9 & 0.00 & 0.62 \\
\hline 2.9 & 5.4 & 4.2 & 0.47 & 0.23 & 2.4 & 3.2 & 2.8 & 0.00 & 0.56 \\
\hline 5.4 & 8 & 6.7 & 0.59 & 0.06 & 3.2 & 4.6 & 3.9 & 0.15 & 0.47 \\
\hline 8 & 10.9 & 9.5 & 0.66 & 0.03 & 4.6 & 7.2 & 5.9 & 0.35 & 0.33 \\
\hline 10.9 & 14 & 12.5 & 0.62 & 0.01 & 7.2 & 9.4 & 8.3 & 0.55 & 0.13 \\
\hline 14 & 16.3 & 15.2 & 0.58 & 0.02 & 9.4 & 12.1 & 10.8 & 0.57 & 0.03 \\
\hline \multirow[t]{4}{*}{16.3} & 18.8 & 17.6 & 0.57 & 0.02 & 12.1 & 14.8 & 13.5 & 0.51 & 0.03 \\
\hline & & & & & 14.8 & 18.9 & 16.9 & 0.51 & 0.01 \\
\hline & & & & & 18.9 & 22.4 & 20.7 & 0.46 & 0.01 \\
\hline & & & & & 22.4 & 26.4 & 24.4 & 0.54 & 0.01 \\
\hline
\end{tabular}


Table 5 continued

\begin{tabular}{|c|c|c|c|c|c|c|c|c|c|}
\hline \multicolumn{5}{|c|}{$\mathrm{NaCl}+\mathrm{KOH}$ Mortar 90d } & \multicolumn{5}{|c|}{$\mathrm{NaCl}+\mathrm{KOH}$ Mortar 180d } \\
\hline $\begin{array}{l}\text { Start } \\
{[\mathrm{mm}]}\end{array}$ & $\begin{array}{l}\text { End } \\
{[\mathrm{mm}]}\end{array}$ & $\begin{array}{l}\text { Average } \\
\text { Depth } \\
{[\mathrm{mm}]}\end{array}$ & $\begin{array}{l}\mathrm{Ca}(\mathrm{OH})_{2}[\mathrm{wt} \% / \\
\text { g dry sample] }\end{array}$ & $\begin{array}{l}\mathrm{Cl} \text { cont. }[\mathrm{wt} \% / \mathrm{g} \\
\left.\text { sample } 105^{\circ} \mathrm{C}\right]\end{array}$ & $\begin{array}{l}\text { Start } \\
{[\mathrm{mm}]}\end{array}$ & $\begin{array}{l}\text { End } \\
{[\mathrm{mm}]}\end{array}$ & $\begin{array}{l}\text { Average } \\
\text { Depth } \\
{[\mathrm{mm}]}\end{array}$ & $\begin{array}{l}\mathrm{Ca}(\mathrm{OH})_{2} \\
{[\mathrm{wt} \% / \mathrm{g} \text { dry }} \\
\text { sample] }\end{array}$ & $\begin{array}{l}\mathrm{Cl} \text { cont. [wt } \% / \mathrm{g} \\
\text { sample } 105^{\circ} \mathrm{C} \text { ] }\end{array}$ \\
\hline 0 & 1.1 & 0.6 & 0.69 & 0.30 & 0 & 1.1 & 0.6 & 0.55 & 0.28 \\
\hline 1.1 & 3.2 & 2.2 & 0.99 & 0.25 & 1.1 & 2.1 & 1.6 & 0.89 & 0.31 \\
\hline 3.2 & 5.4 & 4.3 & 1.05 & 0.10 & 2.1 & 3.2 & 2.7 & 1.05 & 0.27 \\
\hline 5.4 & 7.3 & 6.4 & 1.05 & 0.03 & 3.2 & 4.8 & 4 & 1.01 & 0.20 \\
\hline \multirow[t]{7}{*}{7.3} & 9.7 & 8.5 & 1.09 & 0.03 & 4.8 & 7.1 & 6.0 & 1.04 & 0.06 \\
\hline & & & & & 7.1 & 9.1 & 8.1 & 1.05 & 0.03 \\
\hline & & & & & 9.1 & 12.2 & 10.7 & 1.03 & 0.02 \\
\hline & & & & & 12.2 & 15.1 & 13.7 & 1.06 & 0.02 \\
\hline & & & & & 15.1 & 19 & 17.1 & 1.12 & 0.02 \\
\hline & & & & & 19 & 23.1 & 21.1 & 1.11 & 0.02 \\
\hline & & & & & 23.1 & 26.8 & 25.0 & 1.12 & 0.02 \\
\hline \multicolumn{5}{|c|}{$\mathrm{NaCl}+\mathrm{KOH}$ Concrete $90 \mathrm{~d}$} & \multicolumn{5}{|c|}{$\mathrm{NaCl}+\mathrm{KOH}$ Concrete $180 \mathrm{~d}$} \\
\hline $\begin{array}{l}\text { Start } \\
{[\mathrm{mm}]}\end{array}$ & $\begin{array}{l}\text { End } \\
{[\mathrm{mm}]}\end{array}$ & $\begin{array}{l}\text { Average } \\
\text { Depth } \\
{[\mathrm{mm}]}\end{array}$ & $\begin{array}{l}\mathrm{Ca}(\mathrm{OH})_{2}[\mathrm{wt} \% / \\
\text { g dry sample] }\end{array}$ & $\begin{array}{l}\mathrm{Cl} \text { cont. }[\mathrm{wt} \% / \mathrm{g} \\
\left.\text { sample } 105^{\circ} \mathrm{C}\right]\end{array}$ & $\begin{array}{l}\text { Start } \\
{[\mathrm{mm}]}\end{array}$ & $\begin{array}{l}\text { End } \\
{[\mathrm{mm}]}\end{array}$ & $\begin{array}{l}\text { Average } \\
\text { Depth } \\
{[\mathrm{mm}]}\end{array}$ & $\begin{array}{l}\mathrm{Ca}(\mathrm{OH})_{2} \\
{[\mathrm{wt} \% / \mathrm{g} \text { dry }} \\
\text { sample] }\end{array}$ & $\begin{array}{l}\mathrm{Cl} \text { cont. [wt } \% / \mathrm{g} \\
\text { sample } 105^{\circ} \mathrm{C} \text { ] }\end{array}$ \\
\hline 0 & 1.1 & 0.6 & 0.43 & 0.23 & 0 & 0.9 & 0.5 & 0.36 & 0.19 \\
\hline 1.1 & 3.2 & 2.2 & 0.61 & 0.17 & 0.9 & 2 & 1.5 & 0.57 & 0.20 \\
\hline 3.2 & 5.4 & 4.3 & 0.63 & 0.08 & 2 & 2.9 & 2.5 & 0.56 & 0.17 \\
\hline 5.4 & 7.3 & 6.4 & 0.64 & 0.04 & 2.9 & 4.8 & 3.9 & 0.60 & 0.13 \\
\hline \multirow[t]{7}{*}{7.3} & 9.7 & 8.5 & 0.64 & 0.03 & 4.8 & 6.9 & 5.9 & 0.61 & 0.04 \\
\hline & & & & & 6.9 & 8.9 & 7.9 & 0.59 & 0.03 \\
\hline & & & & & 8.9 & 12 & 10.5 & 0.61 & 0.02 \\
\hline & & & & & 12 & 14.9 & 13.5 & 0.61 & 0.02 \\
\hline & & & & & 14.9 & 18.8 & 16.9 & 0.64 & 0.02 \\
\hline & & & & & 18.8 & 22.8 & 20.8 & 0.57 & 0.02 \\
\hline & & & & & 22.8 & 26.6 & 24.7 & 0.59 & 0.02 \\
\hline
\end{tabular}

\section{References}

1. Arya C, Buenfeld NR, Newman JB (1990) Factors influencing chloride-binding in concrete. Cem Concr Res 20(2):291-300. 8846(90)90083-A

2. De Weerdt K, Colombo A, Coppola L et al (2015) Impact of the associated cation on chloride binding of Portland cement paste. Cem Concr Res 68:196-202. https://doi.org/10.1016/ j.cemconres.2014.01.027

3. De Weerdt K, Orsáková D, Geiker MR (2014) The impact of sulphate and magnesium on chloride binding in Portland cement paste. Cem Concr Res 65:30-40. https://doi.org/10. 1016/j.cemconres.2014.07.007

4. Delagrave A, Marchand J, Ollivier J-P et al (1997) Chloride binding capacity of various hydrated cement paste systems.
Adv Cem Based Mater 6(1):28-35. https://doi.org/10.1016/ S1065-7355(97)90003-1

5. Shi Z, Geiker MR, De Weerdt K et al (2017) Role of calcium on chloride binding in hydrated Portland cement-metakaolin-limestone blends. Cem Concr Res 95:205-216. https://doi.org/10.1016/j.cemconres.2017.02.003

6. Tritthart J (1989) Chloride binding in cement II. The influence of the hydroxide concentration in the pore solution of hardened cement paste on chloride binding. Cem Concr Res 19(5):683-691. https://doi.org/10.1016/00088846(89)90039-2

7. Wowra O, Setzer MJ (1997) Sorption of chlorides on hydrated cement and $\mathrm{C}_{3} \mathrm{~S}$ pastes. In: Setzer MJ, Auberg R (eds) Frost resistance of concrete. E \& FN Spon, London, pp 147-153

8. Zhu Q, Jiang L, Chen Y et al (2012) Effect of chloride salt type on chloride binding behavior of concrete. Constr Build 
Mater 37:512-517. https://doi.org/10.1016/j.conbuildmat. 2012.07.079

9. Zibara H, Hooton RD, Thomas MDA et al (2008) Influence of the $\mathrm{C} / \mathrm{S}$ and $\mathrm{C} / \mathrm{A}$ ratios of hydration products on the chloride ion binding capacity of lime-SF and lime-MK mixtures. Cem Concr Res 38(3):422-426. https://doi.org/ 10.1016/j.cemconres.2007.08.024

10. Labbez C, Nonat A, Pochard I et al (2007) Experimental and theoretical evidence of overcharging of calcium silicate hydrate. J Colloid Interface Sci 309(2):303-307. https://doi. org/10.1016/j.jcis.2007.02.048

11. Plusquellec G, Nonat A (2016) Interactions between calcium silicate hydrate (C-S-H) and calcium chloride, bromide and nitrate. Cem Concr Res 90:89-96. https://doi.org/ 10.1016/j.cemconres.2016.08.002

12. International Federation for Structural concrete (fib) (2006) fib Bulletin 34: Model Code for Service Life Design: Model code prepared by Task group 5.6. fib, Lausanne

13. De Weerdt K, Lothenbach B, Geiker MR (2019) Comparing chloride ingress from seawater and $\mathrm{NaCl}$ solution in Portland cement mortar. Cem Concr Res 115:80-89. https://doi. org/10.1016/j.cemconres.2018.09.014

14. De Weerdt K, Orsáková D, Müller ACA et al (2016) Towards the understanding of chloride profiles in marine exposed concrete, impact of leaching and moisture content. Constr Build Mater 120:418-431. https://doi.org/10.1016/j. conbuildmat.2016.05.069

15. Bertolini L, Elsener B, Pedeferri P et al. (2003) Corrosion of steel in concrete: prevention, diagnosis, Repair. Wiley, Weinheim

16. Byfors K (1986) Chloride binding in cement paste. Nordic Concr Res 5:27-38

17. Zibara H (2001) Binding of external chlorides by cement pastes. PhD Thesis, University of Toronto

18. Luping T, Nilsson L-O, Basheer PAM (2012) Resistance of concrete to chloride ingress, 1st edn. Spon Press, London and New York

19. Hemstad P, Machner A, De Weerdt K (2020) The effect of artificial leaching with $\mathrm{HCl}$ on chloride binding in ordinary Portland cement paste. Cem Concr Res 130:105976. https:// doi.org/10.1016/j.cemconres.2020.105976

20. NT BUILD 443 (1995) Concrete, hardened: Accelerated chloride penetration. Nordtest

21. EN 13396 (2004) Products and systems for the protection and repair of concrete structures. Test methods. Measurement of chloride ion ingress. CEN

22. ASTM C1543-10a (2010) Standard Test Method for Determining the Penetration of Chloride Ion into Concrete by Ponding (Withdrawn 2019)

23. ASTM C1556-11a (2011) Standard Test Method for Determining the Apparent Chloride Diffusion Coefficient of Cementitious Mixtures by Bulk Diffusion

24. EN 12390-11 (2015) Testing hardened concrete - Part 11: Determination of the chloride resistance of concrete, unidirectional diffusion. CEN

25. Le Bescop P, Lothenbach B, Samson E et al. (2013) Modeling degradation of cementitious materials in aggressive aqueous environments. In: Alexander M, Bertron A, Belie N de (eds) Performance of cement-based materials in aggressive aqueous environments. state-of-the-art report,
RILEM TC 211 - PAE, vol 10. Springer, Dordrecht, pp 177-218

26. Machner A, Zajac M, Ben Haha M et al (2018) Stability of the hydrate phase assemblage in Portland composite cements containing dolomite and metakaolin after leaching, carbonation, and chloride exposure. Cement Concr Compos 89:89-106. https://doi.org/10.1016/j.cemconcomp.2018. 02.013

27. Sevelsted TF, Skibsted J (2015) Carbonation of C-S-H and $\mathrm{C}-\mathrm{A}-\mathrm{S}-\mathrm{H}$ samples studied by ${ }^{13} \mathrm{C},{ }^{27} \mathrm{Al}$ and ${ }^{29} \mathrm{Si}$ MAS NMR spectroscopy. Cem Concr Res 71:56-65. https://doi.org/10. 1016/j.cemconres.2015.01.019

28. Bolte G, Zajac M, Skocek J et al (2019) Development of composite cements characterized by low environmental footprint. J Clean Prod 226:503-514. https://doi.org/10. 1016/j.jclepro.2019.04.050

29. EN 197-1 (2011) Cement, Part I: Composition, specifications and conformity criteria for common cements. CEN

30. EnDurCrete (2018) D3.1 Optimized mix designs using novel binders. WP3

31. EN 206 (2017) Concrete -Specification, performance, production and conformity

32. Kulik DA GEM-Selektor v.3.4

33. Lothenbach B, Winnefeld F (2006) Thermodynamic modelling of the hydration of Portland cement. Cem Concr Res 36(2):209-226. https://doi.org/10.1016/j.cemconres.2005. 03.001

34. Lothenbach B, Durdziński PT, De Weerdt K (2016) Thermogravimetric analysis. In: Scrivener KL, Snellings R, Lothenbach B (eds) A practical guide to microstructural analysis of cementitious Materials. CRC Press Taylor \& Francis Group, Boca Raton, pp 177-211

35. Belda Revert A, De Weerdt K, Hornbostel K et al. (2016) Investigation of the effect of partial replacement of Portland cement by fly ash on carbonation using TGA and SEMEDS. In: Jensen OM, Kovler K, Belie N de (eds) International RILEM Conference on Materials, Systems and Structures in Civil Engineering. Conference segment on Concrete with Supplementary Cementitious Materials. Rilem Publications S.A.R.L., pp 413-422

36. Bary B (2019) Multi-ion transport modelling approach within the EnDurCrete project. Personal Communication

37. Henocq P, Samson E, Marchand J (2012) Portlandite content and ionic transport properties of hydrated $\mathrm{C}_{3} \mathrm{~S}$ pastes. Cem Concr Res 42(2):321-326. https://doi.org/10.1016/j. cemconres.2011.10.001

38. Luping T (2008) Engineering expression of the ClinConc model for prediction of free and total chloride ingress in submerged marine concrete. Cem Concr Res 38(8-9):1092-1097. https://doi.org/10.1016/j.cemconres. 2008.03.008

39. Tang Y-J, Zuo X-B, Yin G-J et al (2018) Influence of calcium leaching on chloride diffusivity in cement-based materials. Constr Build Mater 174:310-319. https://doi.org/ 10.1016/j.conbuildmat.2018.04.112

40. EN 1992 (2004) Eurocode 2: Design of concrete structures. CEN

41. Fjendbo S, Sørensen HE, De Weerdt K, Geiker MR (2021) The square root method for chloride ingress prediction Applicability and limitations. Mater Struct 54: 61. https:// doi.org/10.1617/s11527-021-01643-8 
42. Martín-Pérez B, Zibara H, Hooton RD et al (2000) A study of the effect of chloride binding on service life predictions. Cem Concr Res 30(8):1215-1223. https://doi.org/10.1016/ S0008-8846(00)00339-2

43. Pradelle S, Thiéry M, Baroghel-Bouny V (2016) Comparison of existing chloride ingress models within concretes exposed to seawater. Mater Struct 49(11):4497-4516. https://doi.org/10.1617/s11527-016-0803-y

44. Samson E, Marchand J (1999) Numerical solution of the extended Nernst-Planck model. J Colloid Interface Sci 215(1):1-8. https://doi.org/10.1006/jcis.1999.6145

45. Johannesson B (2000) Transport and Sorption Phenomena in Concrete and Other Porous Media. Report TVBM-1019. $\mathrm{PhD}$ Thesis, Lund Institute of Technology

46. Truc O (2000) Prediction of Chloride Penetration into Saturated Concrete. Multi-species approach. PhD Thesis, Chalmers University of Technology and National Institute of Applied Science, Sweden
47. Marchand J, Samson E, Maltais Y et al (2002) Predicting the performance of concrete structures exposed to chemically aggressive environment - field validation. Mater Struct 35(10):623-631. https://doi.org/10.1007/BF02480355

48. Khitab A, Lorente S, Ollivier J-P (2004) Chloride diffusion through saturated concrete: numerical and experimental results. In: Weiss J, Kovler K, Marchand J et al. (eds) First International RILEM Symposium on Advances in Concrete Through Science and Engineering. RILEM

49. Hosokawa Y, Yamada K, Johannesson B et al. (2008) A development of a multi-species mass transport model considering thermodynamic phase equilibrium. In: Schlangen E, De Schutter G (eds) International RILEM Symposium on Concrete Modelling-ConMod'08. RILEM, pp 543-550

Publisher's Note Springer Nature remains neutral with regard to jurisdictional claims in published maps and institutional affiliations. 